\title{
CD14 Gene (-159 C>T) Polymorphism and its Surface Expression on Monocytes in Pulmonary Tuberculosis Patients
}

\author{
Atia Ali, Romeeza Tahir, Faheem Shahzad, Muhammad Kashif, Shah Jahan, Nadeem Afzal* \\ Department of Immunology, University of Health Sciences, Lahore, Pakistan
}

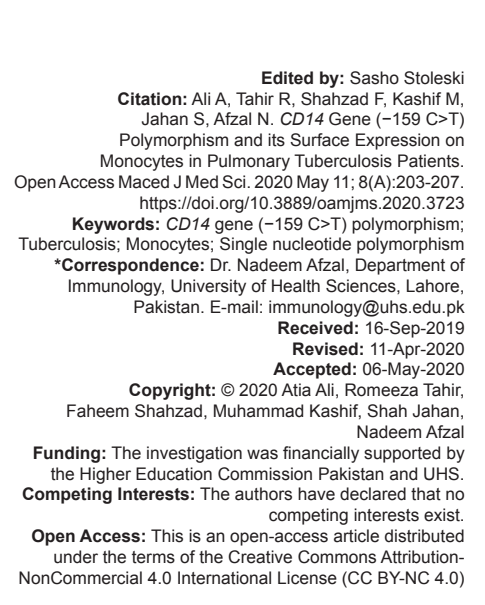

\section{Introduction}

Tuberculosis (TB) is a bacterial infectious disease caused by an acid-fast bacillus; i.e., mycobacterium tuberculosis (MTB). Approximately one-third of the world's population is infected with MTB; however, a relatively small proportion (5-10\%) of infected individuals develops TB disease during their lifetime [1]. Mortality rate of TB has reached up to 1.5-2 million deaths per year; hence, it became second high mortality rate disease after HIVIAIDS [2]. More than half of the world's TB cases (54\%) had been reported in Asia. Pakistan ranks fifth among high TB burden countries where its mortality rate is 26 cases per 100,000 individuals [3].

The host defense mechanisms start with the recognition of MTB by phagocytic cells which bear germ-line encoded pattern recognition receptors (PRR) on their surface [4], [5]. CD14 is one of these receptors encoded by human CD14 gene located on chromosome $5 q 31.3[6]$.

CD14 is a multifunctional glycoprotein antigen that is mainly expressed on monocytes and serves as the marker of identification. It contributes to receptor mediated uptake of non-opsonized MTB through recognizing mycobacterial cell wall components, such as lipoarabinomannan, lipoteichoic acid, and lipoproteins [7]. Activated macrophages upregulate some of their PRRs expression, while CD14 expression is decreased in active TB infection [8].

The blood signatures are promising marker of TB which not only correlates with the magnitude of radiographic findings of the disease but it is also moderated on effective treatment [9]. Variations in the percentage of circulating monocytes and their subsets during MTB infection have already been documented [10], [11].

Host's genetic factors also influence the extent of immune response and hence determine the fate of MTB infection as clinical or sub-clinical [12]. Single nucleotide polymorphism (SNP) of the CD14 gene $(-159 \mathrm{C}>\mathrm{T})$ at position rs2569190 is close to the recognition site of Sp1 transcription factor, and mutant allele T genotype is associated with the increased expression of CD14 [13], [14]. The studies have suggested that CD14-159TT genotype (rs2569190) could be a risk factor for pulmonary TB [15], [16], [17], [18]. Therefore, this study was designed to determine CD14 gene (-159 $\mathrm{C}>\mathrm{T}$ ) polymorphism and surface expression of CD14 
receptor on monocytes before and during treatment of pulmonary TB patients in a local population.

\section{Materials and Methods}

It was a cross-sectional comparative study conducted during April 2017-April 2018 in the Department of Immunology University of Health Sciences (UHS) Lahore Pakistan after approval of Ethical Review Committee of UHS and Gulab Devi Hospital Lahore.

\section{Study subjects}

A total of 159 subjects were recruited from the Gulab Devi Chest Hospital Lahore and they were made into three groups of 53 individuals in each, i.e., pulmonary TB patients before anti-TB treatment, during treatment, and healthy individuals as controls. Pulmonary TB patients were diagnosed on the basis of sputum smear microscopy and chest X-ray. Age, gender, and ethnicity matched unrelated individuals having neither history nor current signs and symptoms of TB infection were recruited as healthy controls. After obtaining a written informed consent $3 \mathrm{ml}$ of venous blood of all the subjects was drawn in EDTA tube.

\section{Flow cytometric analysis for mCD14}

The peripheral blood leukocytes were isolated using lyse-wash method from freshly collected EDTA blood. Monocytes were stained using monoclonal antihuman CD14-FITC and CD45-PerCP antibodies for $10 \mathrm{~min}$ at $4^{\circ} \mathrm{C}$. The final cell suspension was prepared using $500 \mu \mathrm{l}$ of $\times 1$ sheath fluid. Processed samples were acquired and analyzed on FACSCalibur (BD, USA) using software CellQuest. At least 50,000 events were analyzed and percentage of $\mathrm{CD} 45^{+} \mathrm{CD} 14^{+}$monocytes and CD14 mean fluorescence intensity (MFI) was determined.

\section{Polymerase chain reaction-restriction} fragment length polymorphism (PCR-RFLP) for SNP analysis of CD14 gene

Genomic DNA was extracted using phenol chloroform method from the whole blood [19]. PCR was carried out using $100 \mathrm{ng} / \mathrm{uL}$ of extracted DNA and specific set of primers (Forward 5'-TAGATTCTCTGGGATATAAGG-3' and Reverse 5'-CTGACAGTTTATGTAATCCTG-3'). DNA was initially denatured at $94^{\circ} \mathrm{C}$ for $5 \mathrm{~min}$. The cycling conditions were set as denaturation at $95^{\circ} \mathrm{C}$ for $30 \mathrm{~s}$, annealing at $56^{\circ} \mathrm{C}$ for $30 \mathrm{~s}$, and extension at $72^{\circ} \mathrm{C}$ for $45 \mathrm{~s}$ for
35 cycles followed by the final extension at $72^{\circ} \mathrm{C}$ for $5 \mathrm{~min}$. The amplified PCR product was digested with restriction endonuclease, Eco47I (10 units/uL) followed by electrophoresis using $2 \%$ agarose gel to identify different genotypes. The band size of $357 \mathrm{bp}$ indicated CC genotype, 357-217-140 bp indicated CT heterozygous genotype, and 217-140 bp showed TT genotype [20].

\section{Statistical analysis}

The data were entered and analyzed using SPSS 20.0. Mean \pm SD was calculated for quantitative variables whereas frequencies were calculated for qualitative variables. Data were analyzed using Pearson's Chi-Square test, one-way ANOVA and post hoc Tukey's test. Polymorphism analysis and allele frequencies of CD14 (-159 C>T) were compared among the groups using Chi-square test. Odds ratios (OR) and confidence intervals (Cls) were calculated using logistic regression. $p \leq 0.05$ was considered as statistically significant.

\section{Results}

\section{Demographic data of study subjects}

Demographic data of 106 pulmonary TB patients and 53 healthy controls are shown in Table 1. Mean age was compared between groups using independent sample t-test (mean difference $=7.1$ ). A positive correlation of history of smoking and household contact was detected with TB $(21.6 \%$ as compared to $7.4 \%$, $\mathrm{p}=0.01, \mathrm{OR}, 95 \% \mathrm{Cl}=1.3$ and $21.6 \%$ as compared to $9.4 \%, p=0.02, \mathrm{OR}, 95 \% \mathrm{Cl}=1.3$, respectively).

Table 1: Demographic data of the study subjects

\begin{tabular}{|c|c|c|c|c|}
\hline Variables & $\begin{array}{l}\text { Pulmonary TB } \\
\text { cases }(n=106)\end{array}$ & $\begin{array}{l}\text { Healthy } \\
\text { controls }(n=53)\end{array}$ & $p$-value & $\begin{array}{l}\text { Odds ratio } \\
(95 \% \mathrm{Cl}) \\
\end{array}$ \\
\hline \multicolumn{5}{|l|}{ Age (years) } \\
\hline Mean \pm SD & $39.14 \pm 16.2$ & $32.06 \pm 11.5$ & & \\
\hline \multicolumn{5}{|l|}{ Gender } \\
\hline Male n (\%) & $44(41.5)$ & $30(56.6)$ & & \\
\hline Female $\mathrm{n}(\%)$ & $62(58.4)$ & $23(43.3)$ & & \\
\hline Smoking history n (\%) & $23(21.6)$ & $4(7.4)$ & $0.01^{*}$ & $1.3,1.1 \sim 1.6$ \\
\hline Contact history n (\%) & $23(21.6)$ & $5(9.4)$ & $0.02^{*}$ & $1.3,1.0 \sim 1.6$ \\
\hline MDR n (\%) & $6(5.6)$ & --- & & \\
\hline
\end{tabular}

\section{Identification and comparison of $C D 45^{+} C D 14^{+}$monocytes by flow cytometry}

Monocytes were gated first at forward and side scatter plots followed by intersecting two antibodies gates. CD45/CD14 double positive population was gated (Figure 1).

The percentage of $\mathrm{CD} 45^{+} \mathrm{CD} 14^{+}$monocytes and CD14 MFI was compared among TB patients before and after anti-TB treatment and healthy controls 
(Table 2). The percentage of $\mathrm{CD} 45^{+} \mathrm{CD} 14^{+}$monocytes was compared using one-way ANOVA where its mean

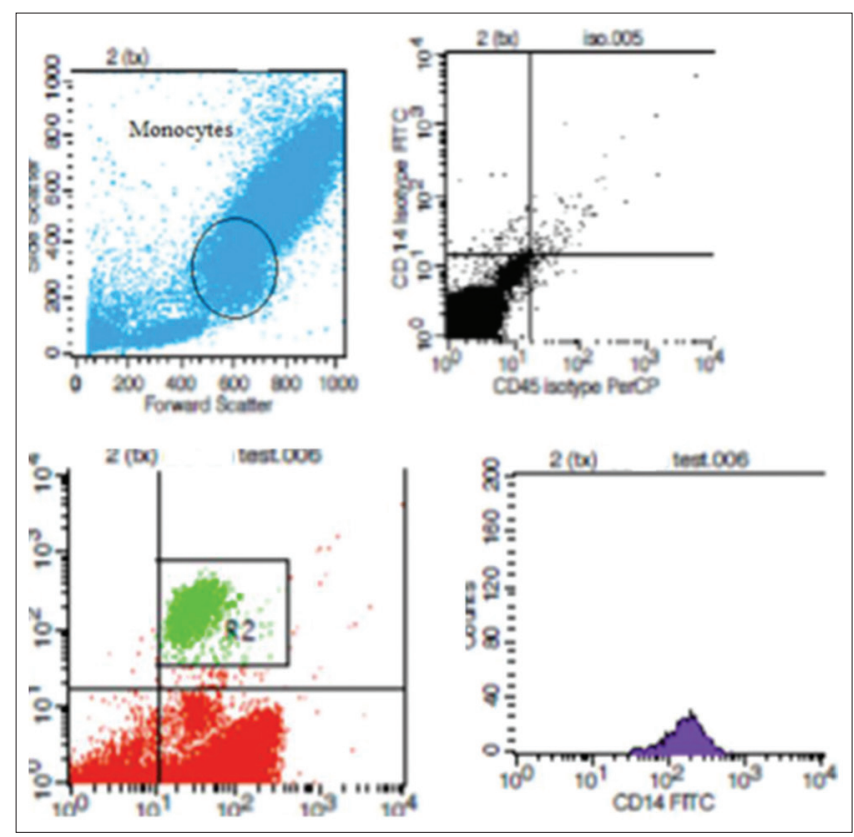

Figure 1: Representative flow cytometric analysis of peripheral blood monocytes in the study cohort. (a) Leukocytes on forward and side scatter with monocytes in encircled area. (b) Isotype control run on CD45-PerCP and CD14-FITC plot. (c) FACS plot for CD45-PerCP and CD14-FITC of representative sample showing gated double positive population in $R 2$ and expressed in percentage of cells. (d) Histogram of CD14-FITC expression on CD $45^{+} C D 14^{+}$monocytes presented as mean fluorescence intensity

was high in TB patients on treatment than TB patients before treatment and healthy controls $(6.1 \%$ as compared to $5.6 \%$ and $5.7 \%$ ) and the difference among these groups was not statistically significant. The median of CD14 MFI was compared using Kruskal-Wallis test which was high in healthy controls as compared to TB patients before and after treatment and the difference was statistically significant (432 as compared to 365 and 193, $p<0.0001$ ) whereas treatment naïve TB patients had high CD14 MFI than TB patients on treatment and its difference was statistically significant (365 as compared to 193, $p<0.0001$ ).

Table 2: Comparison of percentage of CD45 ${ }^{+} \mathrm{CD} 14^{+}$monocytes and CD14 mean fluorescence intensity among the studied groups

\begin{tabular}{lllll}
\hline Variables & $\begin{array}{l}\text { Pulmonary TB } \\
\text { patients before } \\
\text { treatment }\end{array}$ & $\begin{array}{l}\text { Pulmonary } \\
\text { TB patients } \\
\text { on treatment }\end{array}$ & $\begin{array}{l}\text { Healthy } \\
\text { controls }\end{array}$ & p-value \\
\hline $\begin{array}{l}\mathrm{CD} 45^{+} \mathrm{CD} 14^{+}(\%) \\
\quad \text { Mean } \pm \mathrm{SD}\end{array}$ & $5.6 \pm 2.2$ & $6.1 \pm 2$ & $5.7 \pm 1.8$ & 0.2 \\
$\begin{array}{l}\mathrm{CD} 14 \text { mean } \\
\text { fluorescence intensity }\end{array}$ & & & & \\
$\quad \begin{array}{l}\text { Median } \\
\quad \text { Range }\end{array}$ & $\begin{array}{l}\text { 365 } \\
\text { 105-935 }\end{array}$ & 193 & 432 & $<0.0001^{*}$ \\
${ }^{*} \mathrm{p}<0.05=$ Statistically significant. & TB: Tuberculosis. & & $166-964$ & \\
\hline
\end{tabular}

CD14 (-159 C>T) SNP genotype and allele frequencies in pulmonary $T B$ patients and healthy controls are shown in Table 3. Homozygous CC genotype was more frequent in overall study population as compared to $\mathrm{TT}$ genotype. While comparing
Table 3: Comparison of CD14 (-159 C>T) genotype frequencies between study groups

\begin{tabular}{llll}
\hline Variables & TB patients & Healthy controls & p-value \\
\hline Genotypes & & & \\
CC $\mathrm{n}(\%)$ & $49(46.2)$ & $26(49.0)$ & 0.082 \\
CT n (\%) & $29(27.3)$ & $15(28.3)$ & \\
TT n (\%) & $28(26.4)$ & $12(22.6)$ & 0.8 \\
Alleles & & & \\
C $\mathrm{n}(\%)$ & $127(59.9)$ & $67(63.2)$ & \\
C +T n (\%) & $85(40.1)$ & $39(36.7)$ & \\
\hline n=Number, \%=Percentage, $\mathrm{p} \leq 0.05=$ Statistically significant. TB: Tuberculosis.
\end{tabular}

between groups, homozygous TT was slightly higher in pulmonary TB patients as compared to healthy controls (26.4\% as compared to $22.6 \%$ ), but the difference was not statistically significant. The association of exposure to $\mathrm{T}$ allele and pulmonary TB disease was determined using Pearson's Chi-square test. The comparison showed no statistically significant difference.

The CD14 MFI was compared with CD14 (-159 C>T) genotypes and alleles using one-way ANOVA and independent sample t-test, respectively (Table 4). There was no statistically significant difference for median CD14 MFI among CC, CT, and TT genotypes. Mean CD14 MFI was slightly higher for $\mathrm{C}$ allele than T allele (398 as compared to 351 ), but it was not statistically significant.

Table 4: Comparison of CD14 mean fluorescence intensity with CD14 (-159 C>T) genotypes and alleles

\begin{tabular}{lll}
\hline Variables & $\begin{array}{l}\text { CD14 mean fluorescence } \\
\text { intensity (Mean } \pm \text { SD) }\end{array}$ & p-value \\
\hline Genotypes & $398 \pm 201.5$ & 0.2 \\
CC & $329 \pm 165.7$ & \\
CT & $378 \pm 174.8$ & \\
TT & $398 \pm 201$ & 0.1 \\
Alleles & $351 \pm 170$ & \\
C & & \\
T & &
\end{tabular}

\section{Discussion}

In the current study, 53 individuals in each group, i.e., TB patients before the treatment, after anti-TB therapy and healthy controls were included and compared for CD14 gene polymorphism and surface expression on monocytes. Since monocytes/ macrophages have been documented as chief effector cells in defending the host against MTB infection [11], therefore, current study determined percentage of peripheral blood $\mathrm{CD} 45^{+} \mathrm{CD} 14^{+}$monocytes in TB patients before and during treatment and in healthy controls. There was no significant difference among the groups. This finding is in contrast with the previous study which documented an increase in monocyte compartment of peripheral blood in active TB disease [21]. Rakotosamimanana et al. observed reduced fraction of white blood cell count and in particular, monocyte on completion of TB treatment [22].

CD14 MFI in $\mathrm{CD}_{4} 5^{+} \mathrm{CD} 14^{+}$monocytes was compared among study groups to determine the effect of treatment on mCD14. There was highly significant difference in CD14 MFI among the three groups 
( $p<0.0001)$. It was noted that healthy subjects had the highest CD14 MFI followed by TB patients before the therapy whereas patients on anti-TB treatment had the lowest CD14 MFI. These findings are consistent with Guirado et al. who suggested that activated mononuclear phagocytes have increased PRR expression, particularly of mannose receptor, while CD14 expression was decreased during active TB infection [8].

The innate immune response is also regulated by $C D 14$ gene polymorphism [23]. The current study determined the prevalence of CD14 (-159 C>T) gene polymorphism by PCR-RFLP technique and investigated its correlation with the status of TB disease. It was detected that CC genotype was more prevalent in the overall study cohort while TT genotype was more common in TB patients than in healthy controls $(26 \%$ as compared to $22 \%$ ). Similarly, while comparing alleles between the study groups, mutant $\mathrm{T}$ allele was more common in TB patients than in healthy controls, but the difference was not statistically significant. For CD14 (-159 C>T) SNP, C allele is a reference allele in the Asian population [24]. The results of the current study are in agreement with Ayaslioglu et al. (2013) who also performed SNP genotyping through PCR-RFLP and could not detect significant difference in allelic as well as in genotype distribution between TB patients [19].

A study performed in Chinese population documented high frequency of $\mathrm{T}$ allele in $\mathrm{C}(-159) \mathrm{T}$ polymorphism (OR 1.4, Cl 95\%) in TB patients than in controls [17]. Alavi-Naini et al. reported 2.3-fold increased risk of TB disease in individuals with $T$ allele as compared to those without it [25]. In the present study, there was no significant association of $T$ allele with TB disease susceptibility. The reason may be because the current study included genetically different population and smaller cohort.

To investigate whether CD14 (-159 C>T) SNP genotypes have impact on expression of mCD14 on monocyte surface, the current study compared genotypes and alleles with CD14 MFI on CD $45^{+} \mathrm{CD} 14^{+}$ monocytes and no statistically significant effect of CD14 MFI with different CD14 SNP genotypes as well as C or $\mathrm{T}$ alleles was detected. However, $\mathrm{T}$ allele had slightly decreased CD14 MFI as compared to C allele. On the contrary to this, it was reported that mutant allele $T$ genotype is associated with the increased expression of CD14 [13].

\section{Conclusion}

CD14 gene (-159 C>T) polymorphism was not associated with pulmonary TB disease in a sample of Pakistani population and therefore does not support this SNP for TB susceptibility. The surface expression of CD14 receptor on peripheral blood monocytes was decreased in active TB infection which further decreased during anti-TB treatment. It suggests the potential role of CD14 surface expression in monitoring anti-TB treatment.

\section{Acknowledgments}

The authors are extremely thankful to Higher Education Commission Pakistan and UHS for providing financial and logistic support. We also appreciate the medical staff and patients at Gulab Devi Chest Hospital Lahore who participated in this study.

\section{References}

1. O'Garra A, Redford PS, McNab FW, Bloom Cl, Wilkinson RJ, Berry MP. The immune response in tuberculosis. Annu Rev Immunol. 2013;31:475-52. https://doi.org/10.1146/ annurev-immunol-032712-095939

PMid:23516984

2. World Health Organization. Global Tuberculosis Report 2015 2015. Available from: http://www.who.int/tb/publications/global_ report/en. [Last accessed on 2016 May 25].

3. CDC. Reported Tuberculosis in the United States, 2014. Atlanta, Georgia: US Department of Health and Human Services, CDC; 2015. Available from: http://www.cdc.gov/tb/statistics/ reports/2014/pdfs/tb-surveillance-2014 report.pdf. https://doi. org/10.1037/e364332004-001. [Last accessed on 2016 Nov 14]

4. Hossain M, Norazmi MN. Pattern recognition receptors and cytokines in Mycobacterium tuberculosis infection-the doubleedged sword? Biomed Res Int. 2013;2013:179174. https://doi. org/10.1155/2013/179174

PMid:24350246

5. Natarajan K, Kundu M, Sharma P, Basu J. Innate immune responses to $M$. tuberculosis infection. Tuberculosis. 2011;91(5):427-31. https://doi.org/10.1016/j.tube.2011.04.003 PMid:21550855

6. Ferrero E, Goyert SM. Nucleotide sequence of the gene encoding the monocyte differentiation antigen, $\mathrm{CD}_{14}$. Nucleic Acids Res. 1988;16(9):4173. https://doi.org/10.1093/nar/16.9.4173 PMid:2453848

7. Hmama Z, Peña-Díaz S, Joseph S, Av-Gay Y. Immunoevasion and immunosuppression of the macrophage by Mycobacterium tuberculosis. Immunol Rev. 2015;264(1):220-32. https://doi. org/10.1111/imr.12268

PMid:25703562

8. Guirado E, Schlesinger LS, Kaplan G. Macrophages in tuberculosis: Friend or foe. Semin Immunopathol. 2013;35(5):563-83. https://doi.org/10.1007/s00281-013-0388-2 PMid:23864058

9. Cliff JM, Kaufmann SH, McShane H, Helden P, O'garra, A. The human immune response to tuberculosis and its treatment: $A$ view from the blood. Immunol Rev. 2015;264(1):88-102. https:// doi.org/10.1111/imr.12269

PMid:25703554

10. Lastrucci C, Bénard A, Balboa L, Pingris K, Souriant S, 
Poincloux R, et al. Tuberculosis is associated with expansion of a motile, permissive and immunomodulatory $\mathrm{CD} 16^{+}$monocyte population via the IL-10/STAT3 axis. Cell Res. 2015;25(12):133351. https://doi.org/10.1038/cr.2015.123

PMid:26482950

11. Guggino G, Orlando V, Cutrera S, La Manna MP, Di Liberto D, Vanini $\mathrm{V}$, et al. Granzyme a as a potential biomarker of Mycobacterium tuberculosis infection and disease. Immunol Lett. 2015;166(2):87-91. https://doi.org/10.1016/j.imlet.2015.05.01 PMid:26051682

12. Lipner EM, Garcia BJ, Strong M. Network analysis of human genes influencing susceptibility to mycobacterial infections. PloS One. 2016;11(1):e0146585. https://doi.org/10.1371/ journal.pone.0146585 PMid:26751573

13. LeVan TD, Bloom JW, Bailey TJ, Karp CL, Halonen M, Martinez FD, et al. A common single nucleotide polymorphism in the CD14 promoter decreases the affinity of $\mathrm{Sp}$ protein binding and enhances transcriptional activity. J Immunol. 2001;167(10):5838-44. https://doi.org/10.4049/ jimmunol.167.10.5838

PMid: 11698458

14. Su J, Cui J, Xue HT, Tian JH, Zhang JH. Study on the correlation between CD14 gene polymorphism and susceptibility to laryngeal cancer. Eur Rev Med Pharmacol Sci. 2017;21(19):4292-7. PMid:29077168

15. Rosas-Taraco AG, Revol A, Salinas-Carmona MC, Rendon A, Caballero-Olin G, Arce-Mendoza AY. CD14 C (-159) T polymorphism is a risk factor for development of pulmonary tuberculosis. J Infect Dis. 2007;196(11):1698-8. https://doi. org/10.1086/522147

PMid: 18008256

16. Kang YA, Lee HW, Kim YW, Han SK, Shim YS, Yim JJ. Association between the-159C/T CD14 gene polymorphism and tuberculosis in a Korean population. FEMS Immunol Med Microbiol. 2009;57(3):229-35. https://doi. org/10.1111/j.1574-695x.2009.00602.x

PMid:19758335

17. Zhao MY, Xue Y, Zhao ZQ, Li FJ, Fan DP, Wei LL, et al. Association of CD $14 \mathrm{G}(-1145)$ A and C (-159) T polymorphisms with reduced risk for tuberculosis in a Chinese Han population. Genet Mol Res. 2012;11(3):3425-31. https://doi. org/10.4238/2012.september.25.11

\section{PMid:23079836}

18. Miao R, Ge H, Xu L, Xu F. CD14-159C/T polymorphism contributes to the susceptibility to tuberculosis: Evidence from pooled 1,700 cases and 1,816 controls. Mol Biol Rep. 2014;41(5):3481-5. https://doi.org/10.1007/s11033-014-3210-x PMid:24519436

19. Ayaslioglu E, Kalpaklioglu F, Kavut AB, Erturk A, Capan N Birben $\mathrm{E}$. The role of CD14 gene promoter polymorphism in tuberculosis susceptibility. J Microbiol Immunol Infect. 2013;46(3):158-63. https://doi.org/10.1016/j.jmii.2012.05.008

20. Phenol-Chloroform Isoamyl Alcohol (PCl) DNA Extraction [Online]. [Modified from protocols by Barker et al. (1998)] Available from: http://ccoon.myweb.usf.edu/ecoimmunology. org/About_Home.html.

21. Wang J, Yin Y, Wang X, Pei H, Kuai S, Gu L, et al. Ratio of monocytes to lymphocytes in peripheral blood in patients diagnosed with active tuberculosis. Braz J Infect Dis. 2015;19(2):125-31. https://doi.org/10.1016/j.bjid.2014.10.008 PMid:25529365

22. Rakotosamimanana N, Richard V, Raharimanga $V$, Gicquel $B$, Doherty TM, Zumla A, et al. Biomarkers for risk of developing active tuberculosis in contacts of TB patients: A prospective cohort study. Eur Respir J. 2015;46(4):1095-103. https://doi. org/10.1183/13993003.00263-2015

PMid:26250497

23. Ojurongbe O, Funwei RI, Snyder TJ, Aziz N, Li Y, Falade CO, et al. Genetic diversity of CD14 promoter gene polymorphism (rs2569190) is associated with regulation of malaria parasitemia and susceptibility to Plasmodium falciparum infection. Infect Dis (Auckl). 2017;10:1-6. https://doi. org/10.1177/1178633617726781

PMid:28970738

24. Zacarias JM, Alencar JB, Tsuneto PY, Souza VH, Silva CO, Visentainer JE, et al. The influence of TLR4, CD14, OPG, and RANKL polymorphisms in periodontitis: A case-control study. Inflamm Mediators Periodontal Pathog. 2019;2019:10. https:// doi.org/10.1155/2019/4029217

25. Alavi-Naini $R$, Salimi $S$, Sharifi-Mood B, Davoodikia AA, Moody B, Naghavi A. Association between the CD14 gene C-159T polymorphism and serum soluble CD14 with pulmonary tuberculosis. Int J Tuberc Lung Dis. 2012;16(10):1383-7. https:// doi.org/10.5588/ijtld.11.0827

PMid:23107636 